\title{
PROSES BERPIKIR SISWA SEKOLAH MENENGAH ATAS DALAM MEMECAHKAN MASALAH MATEMATIKA BERDASARKAN LANGKAH-LANGKAH POLYA DITINJAU DARI ADVERSITY QUOTIEN
}

\author{
Maryanti $^{(1)}$, Laila Qadriah ${ }^{(2)}$ \\ 12,Universitas Jabal Ghafur
}

\begin{abstract}
ABSTRAK
Matematika memiliki objek yang abstrak sehingga untuk memahaminya tidak cukup hanya dengan menghafal tetapi dibutuhkan adanya proses berpikir. Penelitian ini dilakukan untuk mendeskripsikan proses berpikir dan menganalisa kesulitan siswa dalam memecahkan masalah matematika berdasarkan langkah-langkah Polya ditinjau dari adversity quotient. Penelitian ini merupakan penelitian kualitatif deskriptif yang subjek penelitian adalah siswa kelas XII SMAN 1 Banda Aceh yang terdiri dari tiga siswa. Pemilihan subjek menggunakan teknik pemilihan sampel bertujuan (purposive sampling) dan didasarkan pada tingkat AQ (climber, camper, dan quitter) dan kelancaran komunikasi (lisan dan tulisan) siswa. Pengumpulan data dilakukan dengan menggunakan metode wawancara berbasis tugas, kemudian dilakukan triangulasi untuk memeriksa keabsahan data. Data dianalisis dengan menggunakan konsep Miles dan Huberman: meliputi tahap reduksi data, penyajian data, dan penarikan kesimpulan. Hasil penelitian menunjukkan bahwa; (1) subjek climber melakukan proses berpikir secara asimilasi dalam memahami, menyusun rencana penyelesaian, dan memeriksa kembali penyelesaian masalah. Sementara itu, dalam melaksanakan rencana penyelesaian masalah proses berpikir yang dilakukan adalah asimilasi dan akomodasi. Kesulitan yang dialami subjek climber dalam memecahkan masalah matematika adalah kesulitan dalam memahami beberapa makna soal dari masalah yang diberikan, (2) subjek camper juga melakukan proses berpikir secara asimilasi dalam memahami, menyusun rencana penyelesaian, dan memeriksa kembali penyelesaian masalah. Namun, melakukan proses berpikir secara asimilasi dan akomodasi dalam melaksanakan rencana penyelesaian masalah. Kesulitan yang dialami subjek camper dalam memecahkan masalah matematika disebabkan lupa konsep, kesulitan memahami makna soal dari masalah yang diberikan dan terkadang juga kurang teliti ketika memecahkan masalah, dan (3) subjek quitter melakukan proses berpikir secara asimilasi dan akomodasi dalam memahami dan melaksanakan rencana penyelesaian masalah. Sementara itu, dalam menyusun rencana penyelesaian dan memeriksa kembali penyelesaian masalah dilakukan proses berpikir secara asimilasi. Kesulitan yang dialami subjek quitter dalam memecahkan masalah matematika disebabkan belum memahami dengan baik beberapa konsep dalam matematika, kesulitan memahami makna soal dari masalah yang diberikan dan kurang teliti ketika memecahkan masalah.
\end{abstract}

Kata kunci: Proses Berpikir, Pemecahan Masalah, Langkah-Langkah Polya, Adversity Quotient (AQ).

\section{PENDAHULUAN}

Perkembangan ilmu pengetahuan dan teknologi yang lebih maju dan pesat tidak terlepas dari peran matematika. Untuk itu, manusia sebagai insan yang berhubungan langsung dengan kemajuan teknologi perlu menguasai matematika. Namun, tercapai atau tidaknya tujuan pembelajaran matematika salah satunya dapat dinilai dari keberhasilan siswa dalam memahami matematika dan 
memanfaatkannya untuk menyelesaikan persoalan-persoalan matematika maupun ilmu-ilmu yang lain, untuk itu perlu dilakukan evaluasi atau tes hasil belajar siswa. Akan tetapi prestasi belajar matematika bangsa Indonesia masih rendah.

Data dari hasil Trends in International Mathematics and Science Study (TIMSS) pada tahun 2011 untuk bidang studi matematika yang diikuti siswa kelas XI, Indonesia berada di urutan ke-38 dengan skor 386 dari 42 negara yang siswanya diberi tes (Kompas, 2012). Sedangkan data hasil PISA tahun 2012 juga sangat mengejutkan bangsa Indonesia dan semakin melengkapi rendahnya kemampuan siswa-siswa Indonesia dibandingkan dengan negaranegara lain. Karena hasil PISA yang diumumkan tanggal 4 Desember 2013 menempatkan posisi Indonesia pada urutan ke-64 dari 65 negara partisipan (Kompas, 2013). Hasil PISA tahun 2012 menempatkan mutu pendidikan Indonesia terendah di dunia (Serambi Nasional, 2013). Dari data empirik tersebut terlihat jelas bahwa kemampuan siswa Indonesia secara umum masih sangat rendah khususnya pada bidang studi matematika. Oleh sebab itu perlu adanya perubahan dalam proses pembelajaran matematika di Indonesia, terutama upaya yang dilakukan guru guna mengatasi kesulitan siswa dalam menyelesaikan soal matematika. Salah satu upaya guru yaitu dengan cara melihat bagaimana proses berpikir siswa ketika menyelesaikan masalah matematika. Hal ini diperlukan karena dengan memiliki kemampuan berpikir yang baik, maka siswa akan lebih baik dalam memahami dan menguasai konsep-konsep matematika yang dipelajarinya.

Dengan demikian, pembelajaran matematika sudah seharusnya memberikan penekanan pada proses berpikir siswa. Karena permasalahan yang mendasar yang dialami siswa kita adalah rendahnya kualitas dalam proses berpikir matematika (Jazuli, 2009).

Ngilawajan (2013) juga mengatakan bahwa banyak fakta di lapangan yang masih menunjukkan pembelajaran matematika hanya terlihat sebagai suatu kegiatan yang monoton dan prosedural, yaitu guru menerangkan materi, memberi contoh, menugaskan siswa untuk mengerjakan latihan soal, mengecek jawaban siswa secara sepintas, selanjutnya membahas pemecahan soal yang kemudian dicontoh oleh siswa. Aspek esensial dari pembelajaran, yaitu proses berpikir siswa seolah-olah diabaikan. Padahal salah satu peran guru dalam pembelajaran matematika menurut Yulaelawati (2004) adalah membantu siswa mengungkapkan proses yang berjalan dalam pikirannya ketika menyelesaikan masalah matematika, misalnya dengan cara meminta siswa menceritakan langkah yang ada dalam pikirannya. Hal ini diperlukan untuk mengetahui kesalahan berpikir yang terjadi dan merapikan jaringan pengetahuan siswa. Karena proses berpikir siswa dapat berjalan dengan baik apabila terdapat peran serta guru dalam membantu siswa untuk mendapatkan hasil yang baik dan benar sesuai dengan yang diinginkan. Salah satu contoh peran serta guru adalah dengan menanyakan kembali jawaban yang telah diperoleh siswa sesuai dengan apa yang ada di pikirannya. Dengan demikian guru akan mengetahui sampai dimana pemahaman siswa terhadap materi yang sedang diajarkan, serta guru dapat mengetahui kesalahan-kesalahan yang dilakukan siswa tersebut dalam menyelesaikan masalah matematika. Kesalahan-kesalahan yang dilakukan oleh siswa tersebut dapat dijadikan sumber informasi bagi guru untuk dapat merancang pembelajaran yang sesuai dengan proses berpikir siswa, sebagaimana yang dikatakan Shulman (An, 2012) bahwa "knowledge of 
Jurnal Sosial Humaniora Sigli (JSH)

p ISSN : 2615-3688

$e$ ISSN : 2716-0270

http://journal.unigha.ac.id/index.php/JSH

students' thinking is a major component of pedagogical content knowledge of mathematics teaching".

Proses berpikir merupakan suatu kegiatan mental atau suatu proses yang terjadi di dalam pikiran siswa pada saat siswa dihadapkan pada suatu pengetahuan baru atau permasalahan yang sedang terjadi dan mencari jalan keluar dari permasalahan tersebut. Sudarman (Widodo, 2012) menyatakan bahwa proses berpikir adalah aktivitas yang terjadi dalam otak manusia. Sementara Siswono (2002:45) menyatakan bahwa "proses berpikir adalah suatu proses yang dimulai dengan menerima data, mengolah dan menyimpannya dalam ingatan yang selanjutnya diambil kembali dari ingatan saat dibutuhkan untuk pengolahan selanjutnya". Karena proses berpikir dalam belajar matematika adalah kegiatan mental yang ada dalam pikiran siswa, maka Herbert (Herawati, 1994) menyatakan bahwa untuk mengetahui bagaimana proses berpikir siswa dapat diamati melalui proses cara mengerjakan tes dan hasil yang ditulis secara terurut. Selain itu ditambah dengan wawancara mendalam mengenai cara kerjanya.

Proses berpikir seseorang dapat diamati melalui dua proses, yaitu asimilasi (assimilation) dan akomodasi (accommodation). Menurut Piaget (1969:6) "the filtering or modification of the input is called assimilation and the modification of internal schemes to fit reality is called accommodation". Blake dan Pope (2008) juga mengatakan bahwa asimilasi adalah proses pengintegrasian masalah yang dihadapi ke dalam struktur kognitif yang sudah ada sebelumnya, karena struktur masalah yang dihadapi sesuai dengan skema yang sudah dimiliki. Sementara akomodasi adalah proses perubahan struktur kognitif, karena struktur kognitif yang telah dimiliki belum sesuai dengan struktur masalah yang dihadapi.

Untuk dapat merangsang dan melatih kemampuan berpikir siswa dalam pembelajaran matematika, maka guru perlu menggunakan cara atau teknik yang tepat dalam pembelajaran yang dapat merangsang siswa untuk menggunakan segenap potensi berpikir yang dimilikinya. Cara atau teknik yang tepat yang dapat digunakan dalam pembelajaran untuk melatih siswa berpikir sebagaimana yang telah digunakan dan dibuktikan oleh para ahli melalui sejumlah penelitian adalah melalui pemecahan masalah. Pehkonen (Ngilawajan, 2013) menyatakan bahwa "problem solving has generally been accepted as means for advancing thinking skills". Ini menunjukkan bahwa pemecahan masalah telah dapat diterima secara umum sebagai cara untuk meningkatkan keahlian di dalam berpikir. Someren (1994) juga menyatakan bahwa pemecahan masalah melibatkan proses berpikir dan melibatkan usaha penuh. Hal ini mengartikan bahwa tanpa proses berpikir dan tanpa usaha yang penuh, maka bukan dikatakan memecahkan masalah. Lebih lanjut, NCTM (2010) juga menyatakan bahwa "problem solving plays an important role in mathematics and should have a prominent role in the mathematics education".

Dari beberapa pernyataan di atas, dapat disimpulkan bahwa soal-soal pemecahan masalah dapat digunakan untuk melihat proses berpikir siswa dalam menyelesaikan masalah. Untuk memecahkan masalah, Polya (1973) menawarkan suatu strategi yang terdiri atas empat langkah, yaitu memahami masalah (understanding the problem), menyusun rencana penyelesaian masalah (devising a plan), melaksanakan rencana penyelesaian masalah (carrying out the plan), dan mengecek penyelesaian masalah (looking back).

Dalam memecahkan masalah matematika, setiap orang memiliki cara dan gaya berpikir yang berbeda-beda karena tidak semua orang memiliki kemampuan berpikir yang sama. Terkadang dalam memecahkan masalah matematika ditemukan bahwa ada siswa yang menunjukkan kemampuan yang 
sangat baik, ada siswa yang menunjukkan kemampuan yang biasa saja, dan ada siswa yang mengalami kesulitan. Hal ini dikarenakan, seseorang dapat memecahkan suatu masalah dengan baik apabila didukung oleh kemampuan menghadapi rintangan yang baik pula. Dari sinilah Adversity Quotient (AQ) dianggap memiliki peran penting dalam memecahkan masalah.

AQ merupakan kemampuan yang ada pada diri seseorang dalam menghadapi suatu masalah dan mencari penyelesaian dari masalah tersebut. Menurut Stoltz (2000), AQ adalah kecerdasan seseorang dalam menghadapi dan mengatasi kesulitan secara teratur dan dapat menjadi indikator untuk melihat seberapa kuatkah seseorang dapat terus bertahan dalam suatu masalah yang sedang dihadapinya. AQ terdiri dari tiga tipe, yaitu (1) climbers, merupakan sekelompok orang yang selalu berupaya mencapai puncak kesuksesan, siap menghadapi rintangan yang ada, dan selalu membangkitkan dirinya pada kesuksesan, (2) campers, merupakan sekelompok orang masih ada keinginan untuk menanggapi tantangan yang ada, tetapi tidak mencapai puncak kesuksesan dan mudah puas dengan apa yang sudah dicapai, dan (3) quitters, merupakan sekelompok orang yang lebih memilih menghindar dan menolak kesempatan yang ada, mudah putus asa, mudah menyerah, cenderung pasif, dan tidak bergairah untuk mencapai puncak keberhasilan.

Adapun deskripsi skor berdasarkan tipe AQ menurut Stoltz (2000) adalah: skor 166200 dikategorikan climber, skor 135-165 dikategorikan camper menuju climber, skor 95-134 dikategorikan camper, skor 60-94 dikategorikan quitter menuju camper, dan skor 0-59 dikategorikan quitter. Apabila dikaitkan dengan tingkat AQ yang dimiliki siswa, dimungkinkan bahwa siswa dengan tingkat AQ berbeda tentunya juga akan berbeda dalam proses berpikirnya.

Hal ini didukung oleh penelitian Supardi (2013), yang menyatakan bahwa terdapat pengaruh AQ terhadap prestasi belajar matematika. Dengan kata lain, dapat dikatakan bahwa semakin tinggi tingkat AQ siswa, maka semakin tinggi pula prestasi belajar matematikanya, dan sebaliknya, semakin rendah tingkat AQ siswa, maka semakin rendah pula prestasi belajar matematikanya. Hasil penelitian Sudarman (2011) juga menyimpulkan bahwa siswa yang memiliki AQ rendah (quitter) menghindar dari tugas atau masalah yang diberikan dan dia kurang bersemangat mengerjakan tugas yang diberikan.

\section{METODE PENELITIAN}

Penelitian ini merupakan penelitian kualitatif deskriptif yang subjek penelitiannya adalah siswa kelas XII SMAN 1 Banda Aceh yang terdiri dari tiga siswa. Pemilihan subjek menggunakan teknik pemilihan sampel bertujuan (purposive sampling) dan didasarkan pada tingkat AQ (climber, camper, dan quitter) dan kelancaran komunikasi (lisan dan tulisan) siswa. Untuk pengelompokan siswa ke dalam tiga kategori AQ digunakan angket Adversity Response Profile (ARP) yang dijawab oleh 44 siswa. Dalam penelitian ini, instrumen utama adalah peneliti sendiri. ARP, soal tes pemecahan masalah matematika dan pedoman wawancara sebagai instrumen pendukung.

Pengumpulan data dalam penelitian ini dilakukan dengan menggunakan metode wawancara berbasis tugas yang dilakukan oleh peneliti sendiri kepada setiap subjek ketika menyelesaikan soal pemecahan masalah dengan langkah-langkah Polya. Untuk memeriksa keabsahan data yang diperoleh maka digunakan uji kredibilitas data dengan cara triangulasi. Triangulasi yang digunakan dalam penelitian ini adalah triangulasi waktu, dimana peneliti melakukan pengecekan wawancara subjek pada waktu yang berbeda dengan soal tes pemecahan masalah (TPM) yang berbeda, namun antara TPM-1 dengan TPM-2 memiliki karakteristik yang sama. Teknik analisis data yang digunakan dalam penelitian ini adalah analisis data kualitatif mengikuti konsep 
Miles dan Huberman (1992), yaitu tahap reduksi data, tahap penyajian data, dan tahap penarikan kesimpulan.

\section{HASIL DAN PEMBAHASAN}

\section{Proses Berpikir Siswa dalam Memecahkan Masalah Matematika Ditinjau dari Adversity Quotient}

\section{Proses Berpikir Siswa Climber}

Dalam memecahkan masalah matematika, subjek climber melakukan proses berpikir secara asimilasi dalam memahami masalah, karena subjek climber dapat mengungkapkan informasi-informasi yang diketahui dan ditanya dari masalah yang diberikan dengan benar dan lancar. Selain itu, dalam memahami masalah matematika subjek climber juga dapat memberikan definisi dari prisma dan tinggi limas untuk memberi titik terang mengenai kecukupan data.

Dalam hal ini, subjek climber sudah dapat mengasimilasi informasi ketika ia diminta untuk memahami masalah yang diberikan, karena subjek climber dapat menyebutkan yang diketahui dan yang ditanyakan dengan lancar. Berarti subjek climber dapat mengintegrasikan langsung informasi yang baru diperoleh ke dalam skema yang telah ada dipikirannya. Sebagaimana yang dikemukakan oleh Suparno (2001) bahwa asimilasi adalah proses kognitif yang dengannya seseorang mengintegrasikan persepsi, konsep, atau pengalaman baru ke dalam skema yang sudah ada dalam pikirannya. Hal ini juga senada dengan yang dikemukakan oleh Gage dan Berliner (1984), bahwa assimilation is the process of changing what is perceived so that is fits presents cognitive structures.

Dalam menyusun rencana penyelesaian masalah matematika, subjek climber juga melakukan proses berpikir secara asimilasi, karena subjek climber sudah dapat mengintegrasikan langsung informasi yang baru diperoleh ke dalam skema yang ada dipikirannya. Hal ini dikarenakan juga subjek climber sudah dapat menyebutkan dengan lancar strategi yang dipilih, dapat menggunakan semua data dengan memilih data untuk menyelesaikan masalah, dan dapat meyakini serta memutuskan rencana yang akan digunakan untuk menyelesaikan masalah.

Dalam melaksanakan rencana penyelesaian masalah matematika, secara umum subjek climber melakukan proses berpikir asimilasi dan sebagian kecil melakukan proses berpikir secara akomodasi. Proses berpikir secara asimilasi dilakukan karena subjek climber secara umum dapat melaksanakan dengan lancar setiap langkah penyelesaian dan algoritma perhitungan yang dilakukan juga sudah benar. Subjek climber juga sudah memiliki skema tentang rencana penyelesaian masalah yang diberikan. Dengan demikian subjek climber sudah dapat mengasimilasi dan mengintegrasikan langsung informasi yang baru diperoleh ke dalam skema yang telah ada dipikirannya dalam melaksanakan rencana penyeselesaian masalah matematika. Hal ini senada dengan pernyataan Ormrod (2008:41) bahwa "asimilasi merupakan proses merespon terhadap suatu objek atau peristiwa sesuai dengan skema yang telah dimiliki”.

Proses berpikir secara akomodasi dilakukan karena subjek climber mengalami kesulitan dan bahkan salah di dalam memahami pertanyaan: jika piala adipura akan diberikan kepada 20 kota di tahun 2015, maka hitunglah volume keseluruhan emas dan perak yang dibutuhkan?. Setelah diminta untuk dibaca dan dipahami lagi secara teliti, subjek climber dapat memahami maksud soal pada permasalahan yang kedua. Hal ini sesuai dengan pernyataan Suparno (2001) bahwa akomodasi terjadi jika seseorang tidak dapat mengasimilasikan pengalaman baru yang diperoleh dengan skema yang sudah ada, disebabkan pengalaman baru itu tidak sesuai dengan skema yang telah ada.

Dalam memeriksa kembali penyelesaian masalah matematika, subjek climber melakukan proses berpikir secara 
asimilasi, karena langkah pemeriksaan kembali yang dilakukan sudah sesuai dengan indikator proses berpikir asimilasi. Subjek climber sudah dapat memeriksa kesesuaian hasil dengan data yang diketahui dan dapat memutuskan serta yakin jawaban akhir adalah benar. Dengan demikian dapat dikatakan bahwa subjek climber mampu mengasimilasi dan mengintegrasikan langsung informasi yang baru diperoleh ke dalam skema yang ada di dalam pikirannya.

Berdasarkan hasil wawancara dan uraian di atas dapat diketahui bahwa dalam memecahkan masalah matematika, subjek climber tidak pernah mengeluh dan menghindar dari masalah yang diberikan. Jika subjek climber mengalami kesulitan dan keraguan dalam memecahkan masalah, subjek climber tidak pernah putus asa dan terus berusaha untuk dapat menyelesaikan masalah tersebut. Hal ini sejalan dengan teori dari Stoltz (2000) yang menyatakan bahwa orang dengan tipe climber adalah orang yang selalu berusaha untuk mencapai tujuan dan puncak kesuksesan, bahkan ia siap menghadapi rintangan yang ada ibarat orang yang bertekad mendaki gunung sampai ke puncak.

\section{Proses Berpikir Siswa Camper}

Dalam memahami masalah matematika yang diberikan, subjek camper melakukan proses berpikir secara asimilasi. Hal ini dikarenakan subjek camper dapat mengidentifikasi langsung dari setiap yang diketahui dan ditanya dengan benar dan lancar. Selain itu, dalam memahami masalah matematika subjek camper juga dapat memberikan definisi dari prisma dan tinggi limas untuk memberi titik terang mengenai kecukupan data.

Kelancaran subjek camper dalam menyebutkan yang diketahui dan yang ditanyakan menunjukkan ia sudah dapat mengasimilasi dari setiap informasi ketika ia diminta untuk memahami masalah yang diberikan. Berarti subjek camper sudah dapat mengintegrasikan langsung informasi yang baru diperoleh ke dalam skema yang ada dipikirannya. Hal ini sesuai dengan yang dikemukakan oleh Blake dan Pope (2008) bahwa asimilasi adalah proses pengintegrasian masalah yang dihadapi ke dalam struktur kognitif yang sudah ada sebelumnya, karena struktur masalah yang dihadapi sesuai dengan skema yang sudah dimiliki.

Dalam menyusun rencana penyelesaian masalah matematika, subjek camper juga melakukan proses berpikir secara asimilasi. Karena subjek camper sudah dapat menyebutkan dengan lancar rencana penyelesaian yang akan digunakan dan sudah dapat mengintegrasikan langsung setiap informasi yang baru diperoleh ke dalam skema yang ada dipikirannya. Selain itu, subjek camper juga sudah dapat menggunakan semua data dengan memilih data untuk menyelesaikan masalah dan dapat meyakini serta memutuskan rencana yang akan digunakan untuk menyelesaikan masalah yang diberikan.

Dalam melaksanakan rencana penyelesaian masalah matematika, subjek camper melakukan proses berpikir secara asimilasi dan akomodasi secara seimbang. Proses berpikir secara akomodasi dilakukan karena subjek camper kurang lancar dalam melaksanakan beberapa langkah penyelesaian dan terjadi kesilapan serta salah di dalam memahami pertanyaan: jika piala adipura akan diberikan kepada 20 kota di tahun 2015, maka hitunglah volume keseluruhan emas dan perak yang dibutuhkan?. Bahkan terkadang kurang yakin terhadap jawaban yang diperoleh. Hal ini sesuai dengan indikator proses berpikir akomodasi, yaitu subjek camper tidak lancar menjalankan strategi yang dipilih, melakukan perhitungan yang berulang-ulang, dan tidak dapat memastikan jawaban benar. Santrock (2009) menyatakan bahwa akomodasi (accomodation) terjadi ketika anak menyesuaikan skema mereka agar sesuai dengan informasi dan pengalaman baru mereka. 
Sementara proses berpikir secara asimilasi dilakukan karena algoritma perhitungan yang dilaksanakan sudah benar, baik pada permasalahan pertama maupun pada permasalahan yang kedua. Subjek camper juga sudah memiliki skema tentang rencana penyelesaian masalah yang diberikan. Dengan demikian dapat dikatakan bahwa subjek camper mampu mengasimilasi dan mengintegrasikan langsung informasi yang baru diperoleh ke dalam skema yang ada di dalam pikirannya. Hal ini sejalan dengan pernyataan Melnick (Firmanti, 2014), assimilation is the incorporation of a feature of the environment into already existing structures.

Setelah selesai memecahkan masalah yang diberikan, sebenarnya subjek camper sudah puas dan yakin dengan hasil yang diperolehnya, sehingga ia merasa tidak perlu dilakukan pemeriksaan lagi. Namun, setelah diminta untuk memeriksa kembali jawaban yang diperolehnya, subjek camper melakukan pemeriksaan. Proses berpikir yang dilakukan subjek camper pada saat memeriksa kembali penyelesaian masalah adalah proses berpikir secara asimilasi, karena subjek camper dapat melakukan pemeriksaan dengan lancar dan yakin sekali bahwa hasil akhir yang diperoleh telah benar.

Dari hasil wawancara dan uraian di atas dapat terlihat bahwa dalam memecahkan masalah matematika, subjek camper mudah puas dengan hasil yang telah diperoleh. Hal ini terlihat ketika peneliti meminta subjek camper memeriksa kembali hasil jawaban yang telah diperolehnya, ia tidak segera melakukan pemeriksaan dan kurang semangat untuk memeriksa kembali jawabannya, karena sudah yakin dengan jawaban yang diperolehnya. Hal ini sesuai dengan teori dari Stoltz (2000) yang menyatakan bahwa orang dengan tipe camper adalah orang yang mudah puas dengan apa yang sudah dicapai, sehingga kerap mengabaikan kemungkinan-kemungkinan yang bakal didapat.

\section{Proses Berpikir Siswa Quitter}

Dalam memahami masalah yang diberikan, subjek quitter melakukan proses berpikir secara asimilasi sekaligus akomodasi. Hal ini dikarena subjek quitter dapat mengidentifikasi langsung setiap yang diketahui dan ditanya pada soal. Meskipun subjek quitter juga mengalami kesilapan dalam memahami permasalahan yang pertama karena lupa menyebutkan salah satu yang diketahui pada soal dan tidak lengkap serta kurang lancar dalam memberikan definisi dari prisma dan tinggi limas untuk memberi titik terang mengenai kecukupan data.

Dalam menyusun rencana penyelesaian masalah matematika, subjek quitter melakukan proses berpikir secara asimilasi karena subjek quitter dapat menyebutkan dengan lancar rencana penyelesaian yang akan digunakan. Berarti subjek quitter sudah dapat mengintegrasikan langsung setiap informasi yang baru diperoleh ke dalam skema yang ada dipikirannya. Karena subjek quitter sudah menyebutkan dengan lancar rencana penyelesaian yang dipilih, dapat menggunakan semua data dengan memilih data untuk menyelesaikan masalah, dan dapat meyakini serta memutuskan rencana yang akan digunakan untuk menyelesaikan masalah yang diberikan. Hal ini sesuai dengan pernyataan Piaget (1969:6) "the filtering or modification of the input is called assimilation

Pada langkah melaksanakan rencana penyelesaian masalah matematika, subjek quitter pada umumnya melakukan proses berpikir secara akomodasi dan sebagian kecil melakukan proses berpikir secara asimilasi. Pada umumnya proses berpikir akomodasi dilakukan karena secara umum subjek quitter kurang lancar dalam melaksanakan beberapa langkah penyelesaiannya, baik kesalahan konsep, kesilapan, dan kelupaan terhadap beberapa konsep matematika.

Sementara proses berpikir secara asimilasi dilakukan karena algoritma perhitungan yang dilakukan oleh subjek 
quitter sebagian sudah benar. Subjek quitter juga sudah memiliki skema tentang rencana penyelesaian masalah yang diberikan dan dapat memutuskan rencana apa yang akan dilaksanakan terlebih dahulu. Hal ini sesuai dengan pernyataan Gage dan Berliner (1984), bahwa assimilation is the process of changing what is perceived so that is fits presents cognitive structures.

Setelah selesai memecahkan masalah yang diberikan, subjek quitter sebenarnya tidak berkeinginan lagi untuk melakukan pengecekan/pemeriksaan kembali, namun setelah diminta melakukan pemeriksaan, ia melakukan pemeriksaan kembali jawaban yang diperoleh dengan cara menelaah setiap langkah penyelesaian yang telah dikerjakan. Proses berpikir yang dilakukan subjek quitter ketika memeriksa kembali penyelesaian masalah adalah proses berpikir asimilasi, karena subjek quitter dapat melakukan pemeriksaan dengan lancar dan yakin sekali bahwa hasil akhir yang diperoleh telah benar. Hal ini dapat dikatakan bahwa subjek quitter sudah mengasimilasi dan mampu mengintegrasikan langsung setiap informasi yang baru diperoleh ke dalam skema yang ada di dalam pikirannya ketika ia diminta memeriksa kembali penyelesaian masalah yang telah dikerjakan.

Dari hasil wawancara dan uraian di atas dapat terlihat bahwa dalam memecahkan masalah matematika, subjek quitter banyak terdapat kesulitan dan kesalahan konsep. Bahkan ketika diajak untuk menyelesaikan permasalahan yang pertama dan yang kedua serta wawancara, ia beberapa kali menghindar dengan berbagai alasan. Subjek quitter juga membutuhkan waktu yang lama ketika menyelesaikan permasalahan yang diberikan. Hal ini sesuai dengan teori dari Stoltz (2000) yang menyatakan bahwa orang dengan tipe quitter adalah orang yang berusaha menjauh dari permasalahan. Hasil penelitian tentang proses berpikir subjek quitter ini juga sama dengan hasil penelitian yang dilakukan oleh Sudarman (2011), hasil penelitiannya diperoleh bahwa siswa quitter menghindar dari tugas atau masalah yang diberikan, ia kurang bersemangat mengerjakan tugas yang diberikan, dan memerlukan waktu yang sangat lama ketika menyelesaikan masalah yang diberikan.

\section{Kesulitan-Kesulitan Siswa dalam Memecahkan Masalah Matematika Ditinjau dari Adversity Quotient (AQ).}

Subjek quitter banyak mengalami kesulitan ketika memecahkan permasalahan yang pertama, seperti sulit dalam memberikan definisi prisma, menentukan tinggi limas, dan menyederhanakan bentuk akar. Akibat dari kesulitan yang dialaminya, subjek quitter melakukan beberapa kesalahan ketika memecahkan permasalahan. Hal ini senada dengan yang dikemukakan oleh Soedjono (1994:4) bahwa "kesulitan siswa dalam menggunakan konsep telihat ketika siswa lupa nama singkatan/nama teknik suatu objek dan ketidakmampuan untuk mengingat".

Kesulitan dalam memecahkan permasalahan yang pertama juga dialami oleh subjek camper dalam menyederhanakan bentuk akar, operasi bentuk akar, bahkan terdapat kekeliruan dalam menggunakan konsep perbandingan pada segitiga yang sebangun ketika menentukan panjang sisi alas prisma. Kesulitan subjek camper dalam menyederhanakan bentuk akar dan operasi bentuk akar disebabkan lupa konsep. Hal ini senada dengan pernyataan Widdiharto (2008:15) bahwa "kesulitan dalam matematika ditandai oleh tidak mengingat satu syarat atau lebih dari suatu konsep".

Kesulitan yang dialami oleh ketiga subjek (quitter, camper dan climber) juga terdapat pada permasalahan yang pertama, yaitu kesulitan dalam memahami makna kecukupan data. Subjek climber tidak berani mengatakan datanya sudah cukup, karena untuk menyelesaikan masalah selanjutnya masih ada data yang belum diketahui. Subjek camper juga kurang yakin kalau data yang diberikan sudah cukup, sehingga subjek camper mengatakan sepertinya data sudah 
cukup tapi data lain yang diperlukan untuk menyelesaikan masalah masih belum diketahui. Sedangkan subjek quitter mengatakan datanya lebih dari cukup, karena ia berpikir bahwa volume udara diluar prisma dapat ditentukan karena prisma berada di dalam limas. Oleh sebab itu, subjek quitter mengatakan datanya lebih dari cukup. Ia tidak memahami bahwa maksud dari kecukupan data adalah kecukupan informasi yang diberikan pada soal, yaitu yang diketahui pada soal sehingga dapat membantu dalam menyelesaikan masalah yang diberikan.

Hal ini disebabkan mereka tidak memahami secara bahasa makna kecukupan data. Permasalahan ini sejalan dengan pernyataan Lerner (1981), bahwa kesulitan dalam bahasa dan membaca termasuk karakteristik siswa yang berkesulitan dalam belajar matematika. Hasil penelitian Prakitipong dan Nakamura (2006) juga menyimpulkan bahwa kinerja buruk siswa dalam menyelesaikan masalah matematika sangat jelas sekali berkaitan dengan bahasa dan pemahaman konseptual. Hal inilah yang menyebabkan guru bahasa Thailand dan matematika harus bekerja sama dalam mempertimbangkan metode pengajaran yang sesuai bagi siswa.

Pada permasalahan yang kedua, subjek quitter juga kurang lancar dalam memecahkan masalah matematika yang diberikan. Hal ini dikarenakan subjek quitter banyak mengalami kesulitan, seperti sulit dalam memberikan definisi tinggi limas, memahami limas segi empat, bentuk prisma, limas terpancung, dan operasi bentuk akar. Akibat kesulitan ini, subjek quitter melakukan beberapa kesalahan ketika memecahkan masalah. Kesulitan dan kesalahan yang dilakukan oleh subjek quitter senada dengan hasil penelitian Muzangwa dan Chifamba (2012) bahwa miskonsepsi merupakan salah satu akibat dari pemahaman yang buruk terhadap konsep dari materi tersebut.
Subjek camper juga mengalami kesulitan dalam memecahkan permasalahan yang kedua, yaitu kesulitan dalam menggunakan sifat pangkat pada bentuk akar dan terjadi kesilapan ketika mensubtitusikan volume emas dan piala. Kesulitan dalam menggunakan sifat pangkat pada bentuk akar disebabkan subjek camper telah lupa konsep.

Pada permasalahan kedua, ketiga subjek (climber, camper, quitter) juga kesulitan dalam memahami makna soal: jika piala adipura akan diberikan kepada 20 kota di tahun 2015, maka hitunglah volume keseluruhan emas dan perak yang dibutuhkan?. Hal ini sesuai dengan pernyataan Lerner (1981), bahwa kesulitan dalam bahasa dan membaca termasuk salah satu karakteristik siswa yang berkesulitan dalam belajar matematika.

Berdasarkan uraian di atas, dapat diketahui bahwa kesulitan yang dialami siswa dalam memecahkan masalah matematika ditinjau dari AQ disebabkan: (1) siswa belum memahami dengan baik dan lupa konsep prisma, limas, limas terpancung, garis/bidang sejajar, kesebangunan, dan operasi bentuk akar, (2) siswa kurang teliti dalam memecahkan masalah, dan (2) siswa kesulitan memahami beberapa makna soal dari masalah yang diberikan.

\section{SIMPULAN DAN SARAN Simpulan}

Dari analisis dan pembahasan yang telah diuraikan, maka dapat ditarik simpulan sebagai berikut: (1) Proses berpikir secara asimilasi dilakukan oleh subjek climber dan camper dalam memahami, menyusun rencana penyelesaian, dan memeriksa kembali penyelesaian masalah. Sementara subjek quitter melakukan proses berpikir secara asimilasi dalam menyusun rencana penyelesaian dan memeriksa kembali penyelesaian masalah. (2) Proses berpikir secara asimilasi dan akomodasi dilakukan oleh subjek climber dan camper dalam melaksanakan rencana penyelesaian masalah. Sementara subjek quitter 
Jurnal Sosial Humaniora Sigli (JSH)

p ISSN : 2615-3688

$e$ ISSN : 2716-0270

http://journal.unigha.ac.id/index.php/JSH

melakukan proses berpikir secara asimilasi dan akomodasi dalam memahami dan melaksanakan rencana penyelesaian masalah. (3) Kesulitan yang dialami oleh subjek climber dalam memecahkan masalah matematika adalah kesulitan dalam memahami beberapa makna soal dari masalah yang diberikan. Kesulitan yang dialami oleh subjek camper dalam memecahkan masalah matematika disebabkan lupa konsep, kesulitan memahami makna soal dari masalah yang diberikan dan terkadang juga kurang teliti ketika memecahkan masalah. Sementara kesulitan yang dialami oleh subjek quitter dalam memecahkan masalah matematika disebabkan belum memahami dengan baik beberapa konsep dalam matematika, kesulitan memahami makna soal dari masalah yang diberikan dan kurang teliti ketika memecahkan masalah.

\section{Saran}

Berdasarkan simpulan di atas, maka disarankan beberapa hal sebagai berikut: (1) Dalam pembelajaran matematika, guru hendaknya membiasakan siswa dalam menyelesaikan permasalahan yang berkaitan dengan problem solving dengan tahapan penyelesaian masalah yang ditawarkan oleh Polya. (2) Dalam pembelajaran matematika, guru hendaknya memperhatikan proses berpikir siswa ketika menyelesaikan masalah matematika. (3) Dalam pembelajaran matematika, guru hendaknya memperhatikan kemampuan siswa dalam mengatasi kesulitan (tipe AQ siswa). (4) Dalam pembelajaran matematika, guru dapat menjadikan tipe AQ siswa sebagai salah satu alternatif di dalam membentuk kelompok belajar. (5) Dalam pembelajaran matematika, guru harus dapat memberikan motivasi dan perhatian yang lebih kepada siswa tipe quitter ketika menyelesaikan soal pemecahan masalah.

\section{DAFTAR PUSTAKA}

An, Shuhua, \& Wu, Zhonghe. (2012). Enhanching Mathematics Teachers'
Knowledge of Students' Thinking from Assessing and Analyzing Misconceptions in Homework. International Journal of Science and Mathematics Education, 10, 717-753.

Blake, Barbara, \& Pope, Tambra. (2008). Developmental Incorporating Piaget's and Vygotsky's Theories in Classrooms. Journal of Cross-Disciplinary Perspectives in Education, 1 (1), 5967.

Firmanti, Pipit. (2014). The Process of Deductive Thinking at 8th Grade Students with High Math Skill in Completing Geometric Proof. Proceeding of International Conference on Research, Implementation and Education of Mathematics and Sciences 2014, Yogyakarta State University, 391398.

Gage, N. L. \& Berliner, D. (1984). Educational Psychology Third Edition. Boston: Houghton Mifflin Company.

Harian Kompas, (14 Desember 2012). Prestasi Sains dan Matematika Indonesia Menurun.

(5 Desember 2013). Skor PISA: Posisi Indonesia Nyaris Jadi Juru Kunci.

Herawati, Susi. (1994). Penelusuran Kemampuan Siswa Sekolah Dasar dalam Memahami Bangun-bangun Geometri. (Studi Kasus di kelas V SD No. 4 Purus Selatan). Tesis magister, tidak diterbitkan, IKIP Malang.

Jazuli, Akhmad. (2009). Berpikir Kreatif dalam Kemampuan Komunikasi Matematika. Prosiding Seminar 
Jurnal Sosial Humaniora Sigli (JSH)

p ISSN : 2615-3688

e ISSN : 2716-0270

http://journal.unigha.ac.id/index.php/JSH

Nasional Matematika dan Pendidikan

Matematika Jurusan Pendidikan

Matematika FMIPA UNY, Volume 2, 209-220.

Lerner, J. W .(1981). Learning disabilities : Theories, diagnosis, dan teaching strategies. Boston: Houghton Mifflin Company.

Miles, M. B., \& Huberman. A. (1992) . Analisis Data Kualitatif. Terjemahan oleh Tjetjep Rohendi Rohidi. Jakarta: Unversitas Indonesia.

Muzangwa, J., \& Chifamba, P. (2012). Analyis of Errors and Misconceptions in the Learning of Calculus by Undergraduate Students. Acta Didactica Napocencia, 5(2), 1-10.

NCTM. (2010). Why is Teaching with Problem Solving Important to Student Learnig?. Diakses pada tanggal 28 Februari 2014, dari http://www.nctm.org

/Research_brief_14_-

_Problem_Solving.pdf

Ngilawajan, D. A. (2013). Proses Berpikir Siswa SMA dalam Memecahkan Masalah Matematika Materi Turunan Ditinjau dari Gaya Kognitif Field Independent dan Field Dependent. Pedagogia, 1 (2), 71-83.

Ormrod, J. E. (2008). Psikologi Pendidikan (Membantu Siswa Tumbuh dan Berkembang). Penerjemah: Amitya Kumara. Jakarta: Erlangga.

Piaget, J., \& Inhelder, B. (1969). The Psychology of the Child. London and Henley: Routledge \& Kegan Paul

Polya, G. (1973). How to Solve It: A New Aspect of Mathematical Method.
New Jersey: Priceton University Press.

Prakitipong, N., \& Nakamura, S. (2006). Analysis of Mathematics Performance of Grade Five Students in Thailand Using Newman Procedure. Journal of International Cooperation in Education, 9(1), 111122.

Santrock, J. W. (2009). Psikologi Pendidikan. Jakarta: Salemba Humanika.

Serambi Nasional, (7 Desember 2013). Mutu Pendidikan RI Terendah di Dunia.

Siswono, T. Y. E. (2002). Proses Berpikir Siswa dalam Pengajuan Soal. Konferensi Nasional Matematika XI, 22-25 Juli 2002, Malang.

Soedjadi, R. (2000). Kiat Pendidikan Matematika di Indonesia: Konstatasi Keadaan Masa Kini Menuju Harapan Masa Depan. Jakarta: Direktorat Jenderal Pendidikan Tinggi Departemen Pendidikan Nasional.

Soedjono. (1994). Diagnosis Kesulitan Belajar dan Pengajaran Remedial Matematika. Jakarta: Depdikbud.

Someren, V., Maarten, W.Y.F.B., \& Jacobijn A.C.S. (1994). The Think Aloud Method: A Pratical Guide to Modelling Cognitive Processes. London: Academic Press.

Stoltz, P. G. (2000). Adversity Quotient: Mengubah Hambatan Menjadi Peluang. Jakarta: Gramedia Widiasarana Indonesia.

Sudarman. (2011). Proses Berpikir Siswa Quitter pada Sekolah Menengah Pertama dalam Menyelesaikan 
Jurnal Sosial Humaniora Sigli (JSH)

p ISSN : 2615-3688

$e$ ISSN : 2716-0270

http://journal.unigha.ac.id/index.php/JSH

Masalah Matematika. Edumatica, 1 (2), 15-24.

Supardi, U. S. (2013). Pengaruh Adversity Quotient Terhadap Prestasi Belajar Matematika. Formatif, 3(1), 61-71.

Suparno, P. (2001). Teori Perkembangan Kognitif Jeans Piaget. Yogyakarta: Kanisius.

Widdiharto, Rachmadi. (2008). Diagnosis Kesulitan Belajar Matematika SMP dan Alternatif Proses Remidinya. Jakarta: Depdiknas.

Widodo, S.A. (2012). Proses Berpikir Mahasiswa dalam Menyelesaikan Masalah Matematika Berdasarkan Dimensi Healer. Prosiding, FMIPA UNY, 85,796-800.

Yulaelawati. E. (2004). Kurikulum dan Pembelajaran: Filosofi Teori dan Aplikasi. Bandung: Pakar Raya. 